\title{
Carotid Plaque Echogenicity and Risk of Nonvertebral Fractures in Women: A Longitudinal Population-Based Study
}

\author{
L. Jørgensen - O. Joakimsen - E. B. Mathiesen · \\ L. Ahmed · G. K. R. Berntsen · V. Fønnebø · \\ R. Joakimsen · I. Njølstad $\cdot$ H. Schirmer · B. K. Jacobsen
}

Published online: 17 June 2009

(C) Springer Science+Business Media, LLC 2009

Erratum to: Calcif Tissue Int (2006) 79(4): 207-213

\section{DOI 10.1007/s00223-006-0071-x}

Due to a technical error, a number of fractures had not been included in the database.

Among the 2733 women included in the study, 389 (not 283 as stated in the publication) women suffered at least one non-vertebral fracture during follow-up. The main result was unchanged after reanalysis, however.

The risk of fracture was significantly higher among subjects with echogenic plaques than among subjects without plaques, $\mathrm{RR}=1.6$ (95\% CI: $1.1-2.5$ ) when adjusted for age (see Table 2).

We apologize for any inconvenience caused by our mistake.

Table 2 Relative risk (RR) for non-vertebral fractures in relation to the prevalence of plaques

\begin{tabular}{lcccccccc}
\hline Plaque echogenicity & $\begin{array}{l}\text { Total without } \\
\text { fractures }\end{array}$ & $\begin{array}{l}\text { Total with } \\
\text { fractures }\end{array}$ & RR $^{\mathrm{a}}$ & 95\% CI & $\mathrm{RR}^{\mathrm{b}}$ & 95\% CI & RR & 95\% CI \\
\hline No plaques & 1193 & 181 & 1.0 & & 1.0 & 1.0 \\
Echolucent and predominantly echolucent & 402 & 64 & 1.0 & $0.8-1.3$ & 1.0 & $0.8-1.3$ & 1.0 & $0.8-1.4$ \\
Predominantly echogenic & 661 & 119 & 1.1 & $0.8-1.3$ & 1.0 & $0.8-1.3$ & 1.0 & $0.8-1.3$ \\
Echogenic & 88 & 25 & 1.6 & $1.1-2.5$ & 1.5 & $1.0-2.3$ & 1.6 & $1.0-2.4$ \\
\hline
\end{tabular}

${ }^{a}$ Adjusted for age

b Adjusted for age and BMD

c Adjusted for age, BMD, body height, body mass index; serum high density lipoprotein, number of smoking years, grip strength

The online version of the original article can be found under doi:10.1007/s00223-006-0071-x.

L. Jørgensen $(\bowtie) \cdot$ O. Joakimsen · L. Ahmed ·

V. Fønnebø · I. Njølstad · B. K. Jacobsen

Institute of Community Medicine, University of Troms $\varnothing$,

Breivika, 9037 Tromso, Norway

e-mail: lone.jorgensen@ism.uit.no

O. Joakimsen - E. B. Mathiesen - G. K. R. Berntsen ·

R. Joakimsen $\cdot$ H. Schirmer

University Hospital of North Norway,

Breivika, Tromso, Norway

E. B. Mathiesen

Institute of Clinical Medicine, University of Troms $\varnothing$,

Breivika, 9038 Tromso, Norway 